\title{
Teacher Opinions on Use of Self-Regulation Strategies at Science and Art Centers: Turkey Sample
}

\author{
Cevat Eker, Murat İnce* \\ Ereğli Faculty of Education, Zonguldak Bülent Ecevit University, Turkey
}

Copyright $\mathrm{O} 2018$ by authors, all rights reserved. Authors agree that this article remains permanently open access under the terms of the Creative Commons Attribution License 4.0 International License

\begin{abstract}
The purpose of this study is to identify the usage status of self-regulation strategies at Science and Art Centers (BİLSEMs) that provide the gifted students with education in Turkey. This research was designed within qualitative study and survey model was used. It was conducted with 24 teachers at Science and Art Centers each in the Western Black Sea, Marmara and Aegean regions in Turkey. The teacher interview form designed by the researchers was used as the data collection instrument. Descriptive analysis and content analysis methods were used for analyzing the data. It was concluded in the research that the teachers do not find themselves competent about self-regulation strategies. The most observed self-regulation deficiencies among BILSEM students are deficiencies of motivation and meta-cognitive strategies. The teachers think that BILLEM curricula do not aim to bring self-regulation skills to students. It was determined that the activities performed by teachers in BILSEM curricula (Adaptation, Supportive Education, Realizing Individual Abilities, Improving Special Skills, and Project) are rather for actualizing motivation, meta-cognitive and cognitive strategies.
\end{abstract}

Keywords Self-Regulation Strategies, The Gifted, Science and Art Center

\section{Introduction}

\section{Self-Regulation}

Regarded as one of the main principles of social cognitive theory, self-regulation is described as a constructive process through which students set objectives for learning and then regulate and control their own cognitions and behaviors [1] while, according to [2], it is the act of setting objectives, developing strategies to achieve those objectives and controlling what has been gained by the strategies. [3] argues that individuals must acquire not only the ability to manage their own behaviors in the face of environmental events but also the information required for using that ability under appropriate circumstances. Accordingly, self-regulation is about thoughts, emotions and actions planned and guided to achieve personal goals.

[4] suggests that self-regulation is closely related to the ability to gain the skills of focusing one's attention, using time effectively and efficiently, self-confidence, correlating the information units, setting one's learning objectives and strategies, achieving one's own learning objectives and organizing one's learning. [5] defined the concept of self-regulation as students' act of understanding, apprehending and controlling their own learning. [3] defined self-regulation as a cyclical process because feedbacks received from the previous performance is used for the necessary regulations during the attempts at the moment. Such feedbacks and regulations are necessary as personal, behavioral and environmental factors constantly change during learning and performance.

When recognizing self-regulation as students' internalization of the signs needed for thinking, solving the problems and showing a behavior, the first step of self-regulation is accepting that everything has a meaning, the second one is practicing, and the third one is using the signs needed for thinking and solving the problems [6].

In this process, self-regulation includes activities such as focusing on information, organizing the information to remember it later, coding and rehearsing the learned information; efficient use of sources and providing productive studying environment, valuing the learning, knowing the factors that affect learning, and being proud of and happy with one's effort to learn [5].

\section{Self-Regulation Strategies}

Self-regulation strategies refer to the process of students' guiding his/her own emotions, thoughts and behaviors to achieve a goal. These strategies can be learned as every other ability can. How students can use the self-regulation strategies effectively depends on acquiring them properly. 
The self-regulation strategies commonly recognized around the world and used in this study are as follows:

Meta-cognitive strategies: Meta-cognition is defined as individual's knowledge on his/her own cognitive processes. Meta-cognitive self-regulation is composed of three strategies which can be listed as planning, goal setting, monitoring and regulation.

Cognitive strategies: It is stated that cognitive strategies are about cognitive processes and behaviors used by students to deliver a task or achieve a goal during their learning experiences [7]. These are the strategies of rehearsal, elaboration and organization strategies students use for learning, recalling and understanding through managing the effort they make to achieve their goals [1].

Rehearsal strategies: These strategies are used to activate the information on the running memory. They include simple actions such as reading repeatedly to memorize a subject, reading a text loudly or highlighting the sentences. They help students distinguish important information inside the text and keep that information efficient in the short-term memory. Rehearsal strategies have the function of adding meaning to information learned by students to a certain extent and placing it in the mind. They are particularly used in an efficient way in the transfer of information and stimuli from short-term to long-term memory [8].

Elaboration strategies: Helping students make connection among pieces of information and reorganize their ideas to take notes, ask and answer questions and store information in the long-term memory rather than simply copying the information as it is, these strategies bring a deeper meaning to learning [8]. According to [5], elaboration strategies are underpinned not by copying the information as the same but by integrating it with prior knowledge in their memories, adding meanings to it and placing it in the memory. Students expand the information by adding something to make it more meaningful.

Organization strategies: These strategies help the subject to be processed into the memory in a better and deeper manner. According to [7], organization strategies, which are defined as student's regulation of information learned explicitly or implicitly for improving the learning, help learner choose the proper information and make connection between the pieces of information to be learned. Examples of organization strategies include clustering, summarizing and finding the main idea in reading texts. [8] argue that these strategies ensure that subject to be learned is processed into the memory in a better and deeper way. Grouping the concepts, gathering and schematizing the thoughts, drawing a template of any information or developing concept maps are among such strategies. This explanatory concept also helps us understand how individuals act in certain ways. Consequently, motivation is how individuals believe in that they are willing to gain the desired results at the end of certain behaviors (expectation of positive outcomes) and to actualize those results or to learn how to perform these behaviors (high self-efficacy) [5].

Effort-regulation strategies: Effort-regulation strategy refers to the resistance shown in the fight against negative situations through the ability to fight with failure. According to [9], effort-regulation strategies are a self-method and reflect individual's commitment to achieve his/her goals despite challenges or distractions. Effort management is important for academic achievement because it does not only indicate goal commitment but also regulates constant use of learning methods. During the use of effort-regulation strategy, students focus on a given task when doing it and the strategy helps them not be influenced by negative stimuli from outside but make and control their effort to perform the task [4].

Help-seeking strategies: Help-seeking strategies are defined as how students try to get help from more informed people by asking questions to overcome the difficulties during learning. According to [10], it is important for student to know from whom, when and for what to get help. They are more successful than the students who do not known when and from whom to get help. Help-seeking strategies include students' performing the given tasks without getting help from anyone even if they have difficulty in learning, asking for the explanation of concepts which they do not understand during the class, asking another student for help when they do not understand any subject in the class, and trying to identify peers which may help them when necessary in the classroom [9].

Source-management strategies: These strategies refer to how students use the means around them effectively to achieve their goals [9]. They include strategies such as controlling the attention and effort and asking teacher for help. Source-management strategies help students optimize their surroundings and adapt to their surrounding [11].

Strategies of regulating the time and study environment: Strategies of regulating the time and study environment help students manage the time and carry out their academic studies productively and efficiently [13]. Time-regulation strategies involve scheduling, planning and supervising one's study time. This covers not only sparing time for study but also efficient use of the study time and setting realistic goals. Time management diversifies in levels from studying in evenings to weekly study or monthly schedule [11]. Time regulation is regarded as an important activity product for students to self-regulate their present and future learning and academic performance [12].

\section{Science and Art Centers and Self-Regulated Learning}

In 1993, a project study was commenced by the Ministry of National Education (MoNE) about the education of gifted children in Turkey. In this context, Science and Art Centers (BİLSEMs) were opened as education centers 
where educational strategy of grouping is considered for the gifted, gifted students receive education a few days of the week and can improve their skills. These centers were constructed as institutions where children can be taught in the fields of science and art. [14] states, "Science and Art Centers aim to ensure that gifted students become aware of their skills and improve their capacities to use them at maximum." There are 66 BILLSEMs in Turkey [15]. BILLSEMs are managed within the body of Directorate General of Special Education and Guidance Services under Ministry of National Education. At these autonomous educational institutions, preschool, elementary and secondary school students received education pursuant to the related directive. However, according to the recent amendment, gifted students on secondary school and secondary education levels receive education [14]. Gifted or specially-talented students attending these centers continue their basic education at institutions of formal education with their peers. In parallel with their formal education, such students study individually or in groups with their gifted peers from other schools and branch teachers in the field of ability for which they are gifted at BILLSEMs. A modular program was developed in consideration of interdisciplinary relations in line with the student-centered understanding of education at these centers. Studies carried out at BILLSEMs are created in the guidance of teachers and in accordance with the individual learning principle. Courses taken by the gifted students are not granted credit in the context of general education [15].

\section{BİLSEM Curricula and Self-Regulated Learning}

These curricula applied for the gifted at BILSEMs are handled within the scope of Directive on Science and Art Centers [16]. The principles of the curricula to be developed at BILLSEMs for the students are as follows in the directive:

- Be student-centered,

- Be interdisciplinary,

- Be in a modular approach,

- Be appropriate for individual learning in the company of counselors,

- Improve creativity,

- Improve meta-cognitive thinking skills,

- Provide values education.

Students' planning particularly in the project production (article h), the statement "Educational-instructional environments are regulated in the way that they are open to any kind of environmental conditions, multi-purposive and open to social and psychological operation and motivating" [14] for increasing student motivation and the statement "...Scientific research techniques are utilized in the education in association with natural sciences, mathematics, linguistic arts, social sciences, art, music and similar fields" for ensuring organization strategies remind of self-regulated learning in the directive.
There are very few studies conducted on curriculum structure of BILLSEM in Turkey [15]. The reasons may include that curriculum is addressed in the scope of the directive and the lack of a curriculum that provides a detailed explanation [16].It is quite important to identify to what extent self-regulated learning skills as one of the key skills in the gifted education [17] are applied at BILLSEMs where education is provided for gifted students in Turkey and to identify instructors' levels of knowledge and practice for bringing these skills to the students.

\section{Purpose of the Research}

The purpose of the study is to investigate instructors' levels of knowledge and practice about self-regulated learning at Science and Art Centers where gifted students receive education in Turkey. The following research questions are formulated for the purpose of investigation:

1. What are self-regulated learning knowledge levels of the teachers in charge of education of the gifted students?

2. What are practice levels of the teachers in charge of education of the gifted students for self-regulated learning strategies in curricula?

\section{Methods}

\section{Research Design}

This is a descriptive study which aimed to identify the use of self-regulation strategies at Science and Art Centers providing the gifted students with education in Turkey. It used the case study design which is also used in qualitative research. Case study is the method through which one or more cases, environments, curricula, social groups or other interrelated systems are examined in depth [18].

\section{Participants}

In phenomenological research, data are obtained from individuals or groups who experience the phenomenon in question or may express that phenomenon. Accordingly, the study was carried out with 24 teachers serving in different branches at Science and Art Centers each in the Western Black Sea, Marmara and Aegean regions. The purposive sampling method was used to create the study group. 15 of the participants are male, 9 are female. 4 of the participants had been working for 1-5 years, 4 for 6-10 years, 10 for $11-15$ years and 6 for 16 years and longer (seniority).

\section{Data Collection Process and Data Analysis}

The "Teacher Information Form" developed by the 
researchers with structured interview questions were used in the data collection. Two teachers serving at Science and Art Centers were interviewed to create the interview questions for preparing the data collection instrument, and expert opinion was received to finalize the interview form. The first part of the interview form asks 5 questions about "personal details" such as "seniority" and "training on gifted education" while the second part asks 5 questions about the "use of self-regulation strategies in the gifted education at Science and Art Centers." The latter 5 questions ask about the Science and Art Center curricula levels of actualizing the self-regulation skills and the self-regulation skills utilized in the activities. A teacher briefing form was included in the interview form for self-regulation skills. The briefing form tried to enable the teachers to associate the activities they perform at the Science and Art Centers with the self-regulation skills. The interview forms were applied in written after the teacher briefing. Descriptive analysis was used for analyzing the data. The obtained data were explained and interpreted through descriptions with prespecified themes, and certain results were achieved in an effort [19]. Sub dimensions of self-regulation (meta-cognitive strategies, cognitive strategies, motivational strategies) were taken as basis in creating the themes in the research. The compliant data related to the theoretical framework were defined and interpreted as findings. The coding was performed by three different researchers to increase the study reliability in an effort. Direct citations were used to enhance the effectiveness of the teacher opinions. The participant teachers were coded as $\mathrm{T} 1, \mathrm{~T} 2 \ldots$ instead of full words such as teacher 1 , teacher $2 \ldots$ Letters " $\mathrm{M}$ " and "F" were used for the male and female participants respectively to specify the participants' genders.

Concepts of validity and reliability are different in qualitative research than in quantitative research. In qualitative research, concepts such as credibility and transparency are used instead [19]. For increasing the credibility (internal validity) of the research, a literature review was performed on the subject and a theoretical framework was established, and the participants were asked questions in accordance with this conceptual framework. Preparation of the interview form, study group, data collection process, data analysis and interpretation were explained in a way that readers could understand in the process of ensuring the research transferability (external validity). The obtained data were coded individually by the three researchers, and the consistency among the codes was calculated. Moreover, direct citations were used to increase the consistency.

\section{Findings}

This section addresses the teacher opinions within the framework of specified themes and identified concepts. Table 1 show the teacher opinions on the Science and Art Center teachers' competence level of self-regulation skills in the teacher interview form.

It is seen that BILSEM teachers' opinions on their competence levels of self-regulation skills gathered in three categories. The teachers generally find themselves incompetent or partially competent. 6 of them reported that they find themselves incompetent (T5,M; T7,M; T8,M; T12,F; T13,M; T21,F). Most of the teachers find themselves partially competent about the self-regulation skills. Two participant teachers reported that they did not receive any training on self-regulation skills but had been using some of the strategies unawares. Two teachers stated, "Although I do not have sufficient knowledge on these strategies, I noticed when I read the information in the appendix that the activities are self-regulated learning strategies" (T8,M; T9,M). One of the teachers stated, "I have not received professional training on the specified matters. I know about them just as any other teacher does" $(T 4, F)$. Four of the participants regard themselves as informed and competent about the self-regulation skills (T2,F; T6,M; T10,F; T14,F). Providing the following statement, one of these teachers (T2,F) reported that she utilizes these skills in her activities at BILLSEM: "I use the source-management when instructing the course, especially the elaboration strategies when instructing the subjects so that students can make meaning of them easily and no difference occurs with the school. I certainly also use strategies such as motivation and rehearsal."

Table 1. BILLSEM teachers' opinions on their competence level of self-regulation skills

\begin{tabular}{cclc}
\hline Theme & \multicolumn{1}{c}{ Subthemes } & \multicolumn{1}{c}{ Codes } & Number of Coding \\
\hline & Incompetent & -No knowledge/idea. & 6 \\
\cline { 2 - 4 } Self-regulation & Partially & -No professional training & \\
Teacher knowledge & -No sufficient knowledge & 14 \\
level: & competent & -Use of certain strategies & \\
& & -Responsibility for one's own learning and self-control & 4 \\
& Competent & -Manage sources; use of elaboration, rehearsal and & \\
& & motivational strategies \\
& & -Sufficient knowledge & \\
\hline
\end{tabular}


Table 2. Self-regulation Skills Not Available among Gifted Students

\begin{tabular}{|c|c|c|c|}
\hline Theme & Subthemes & Codes & Number of Coding \\
\hline \multirow{21}{*}{$\begin{array}{l}\text { Self-regulation } \\
\text { skills not available } \\
\text { among gifted } \\
\text { students }\end{array}$} & \multirow{7}{*}{ Meta-cognitive strategies } & \multirow{7}{*}{$\begin{array}{l}\text {-Unaware of one's intelligence and } \\
\text { skills, } \\
\text {-Lack of confidence } \\
\text {-Afraid of criticism } \\
\text {-Afraid of making mistake } \\
\text {-Not have goals, } \\
\text {-Cannot make plans, } \\
\text {-Cannot conclude, }\end{array}$} & 2 \\
\hline & & & 2 \\
\hline & & & 1 \\
\hline & & & 1 \\
\hline & & & 7 \\
\hline & & & 8 \\
\hline & & & 1 \\
\hline & Cognitive strategies & Lack of cognitive strategies & 5 \\
\hline & \multirow{10}{*}{ Motivational strategies } & \multirow{4}{*}{$\begin{array}{l}\text {-Gets bored quickly, } \\
\text {-Unwillingness, } \\
\text {-Lack of attention, cannot pay attention, } \\
\text {-Lack of motivation, }\end{array}$} & 5 \\
\hline & & & 3 \\
\hline & & & 4 \\
\hline & & & 5 \\
\hline & & \multirow{2}{*}{$\begin{array}{l}\text {-Impatience, } \\
\text {-Cannot focus, }\end{array}$} & 5 \\
\hline & & & 2 \\
\hline & & $\begin{array}{l}\text {-Boredom, } \\
\text {-Laziness, }\end{array}$ & 1 \\
\hline & & -Lack of excitement, & 1 \\
\hline & & Undeveloped sense of responsibility & 2 \\
\hline & & Worry about failure & $\begin{array}{l}1 \\
3\end{array}$ \\
\hline & Effort regulation & -Gives up quickly, & 3 \\
\hline & \multicolumn{2}{|c|}{ Source management } & 3 \\
\hline & \multicolumn{2}{|c|}{ Regulation of time and study environment } & 2 \\
\hline
\end{tabular}

According to Table 2, BILSEM teachers' opinions on the self-regulation skills not available among the gifted students are grouped in 6 categories. The important self-regulation deficiencies among BİLSEM students observed by the teachers are deficiencies of motivation and meta-cognitive strategies. As for the teacher opinions which stated that the students are deficient in meta-cognitive strategies, they reported that the students do not have goals and cannot make plans. One of the participant teachers reported, "The gifted are different. Here are their problems: They do not have goals. They cannot plan and solve any given problem. They generally fail to solve problem. It is not the case for all of them, but it is generally. They have the knowledge; they can go back to it. But they cannot find the solution to the problem. They get bored quickly and are not willing. I think the reason is that BILSEM curricula are not instructed in accordance with the attainments in the directive" $(T 1, F)$.

Another teacher who thought that the students are deficient in motivational strategies stated, "Students act under the guidance of family, environment and school conditions. Plans and goals of others and their parents rather regulate children's lives. One cannot say they have developed sufficient self-regulation skills. There are few students who are both gifted or specially-talented and have high confidence and self-regulation skills" (T7,M).
The teacher who reported that the students are deficient in motivational strategies stated that the students get bored quickly of the activities, cannot focus and are impatient. One of the participants stated, "Meta-cognitive strategies are used regularly and properly among the gifted students. It is observed that they sometimes have trouble with motivation and give up quickly in the face of problems. They are afraid of making mistakes, being criticized and embarrassed" (T1,F). Another teacher who thought that the students are deficient in motivational strategies stated, "They are too hasty in the first place; they do not have the patience to complete the process. Most of them get bored quickly. If they are not interested in that subject, most of the students who are particularly talented in art struggle to motivate in scientific units. They worry about failure. They give up right away" (T12,F).

Two of the teachers who stated that the students are deficient in cognitive strategies $(\mathrm{f}=5)$ reported that students need to be improved in the strategies of elaboration and organization (T8,M; T9,ME). Three of the participant teachers (T10,F; T12,F; T18,E) stated that the students lack in the effort-regulation strategies, three teachers $(\mathrm{T} 8, \mathrm{M}$; $\mathrm{T} 12, \mathrm{~F} ; \mathrm{T} 18, \mathrm{M})$ stated that they lack in the source-management strategies, two teachers (T12,F; $\mathrm{T} 18, \mathrm{M})$ stated that they are deficient in the strategies of regulating time and study environment. 
Table 3 shows that the teacher opinions on whether Science and Art Centers bring self-regulation skills to students are grouped in two categories. Most of the teachers think that BILSEM curricula do not aim to bring self-regulation skills to students. Six of the teacher who thinks that BILSEM curricula do not provide students with self-regulation skills reported that there are no curricula at BILLSEMs. One of the teachers stated, "Steps and contents of the curriculum are limited to a single sentence in the directive now. Therefore, one can say there is no curriculum at all. Of course, self-regulation skills should be included in the content when developing a curriculum" $(T 11, M)$. Another teacher reported, "Current BILSEM curriculum does not have clear objectives about these skills. The skills in question should be included in the content when developing a curriculum. I think that this would be useful for students to be more participative, productive and able to perform better" (T15,M). Five of the teachers who think that BILLSEM curricula do not aim to bring self-regulation skills to the students (T2,F; T8,M; T9,M; $\mathrm{T} 16, \mathrm{M} ; \mathrm{T} 19, \mathrm{M})$ stated that these skills are important for students to be recognized both by themselves and their teachers in a better way and to bring forth their potential.

The teachers who stated that Science and Art Center curricula aim to provide students with self-regulation skills reported that there are contents for bringing the self-regulation skills to students in the curricula they apply and the individualized curricula at BILLSEMs meet this need.
One of the teachers stated, "Since IEP is basically applied at the Science and Art Center, it also involves self-regulation strategies. IEP is developed according to individual's requests and capabilities. What matters here is that students achieve a level which they can be used for life rather than their momentary attainments" (T13,M).

Table 4 indicates the teacher opinions on which self-regulation skills are improved by the activities performed during the adaptation program at Science and Art Centers. The teachers who teach in the adaptation program stated that they rather emphasize the recognition of students and their adaptation to their peers, teachers and the Science and Art Center. It is seen that the activities performed by the teachers are for improving the meta-cognitive strategies and motivational strategies. One of these teachers stated, "The adaptation program rather aims the socialization of students and does not cover direct information transfer. It can be said that it addresses the motivational strategy and the cognitive rehearsal of newly-learned information, even if it is few, through educational games $(T 11, M)$ while another teacher reported, "I am trying to ensure that students from other schools who won BILSEM get to know and mix with each other through educational games in the orientations. I am expecting activities for bringing self-regulation skills such as motivational and help-seeking strategies when choosing the educational games" $(T 18, M)$. Besides the motivational and meta-cognitive strategies, the teachers reported that they also perform activities aiming the cognitive and help-seeking strategies.

Table 3. Whether BILSEM curricula do/should aim self-regulation skills

\begin{tabular}{cllc}
\hline Theme & Subthemes & \multicolumn{1}{c}{ Codes } & Number of Coding \\
\hline & & Similar content & 1 \\
& Yes & Individualized Curricula provide this & 1 \\
Whether BİLSEM curricula & & Yes & 7 \\
\cline { 2 - 3 } aim self-regulation skills & BiLSEM not available, & 6 \\
& No/ & Recognize the student & 5 \\
& Necessary & Identify the skill & 1 \\
& & No & 8 \\
\hline
\end{tabular}

Table 4. Activities of Adaptation Program and Self-Regulation Skills

\begin{tabular}{|c|c|c|c|}
\hline Theme & Subthemes & Codes & Number of Coding \\
\hline \multirow{12}{*}{$\begin{array}{l}\text { ADAPTATIO } \\
\text { N PROGRAM }\end{array}$} & \multirow{3}{*}{ Meta-cognitive strategies } & Skill recognition/perception & 5 \\
\hline & & Decision-making skill & 1 \\
\hline & & Preparedness-awareness & 2 \\
\hline & \multirow{4}{*}{ Cognitive strategies } & Attention test & 1 \\
\hline & & Detective memory & 1 \\
\hline & & Coordinate activity & 1 \\
\hline & & Cognitive rehearsal & 1 \\
\hline & \multirow{3}{*}{ Motivation } & Educational game & 3 \\
\hline & & Responsibility & 1 \\
\hline & & Motivation & 2 \\
\hline & Effort regulation & - & - \\
\hline & Help-seeking & Help-seeking & 1 \\
\hline
\end{tabular}


Table 5 shows the teacher opinions on which self-regulation skills are improved by the activities performed during the supportive training program at Science and Art Centers. It is seen that the activities performed by the teachers who teach in the Support Training program are rather for improving the cognitive strategies. The teachers stated that they try to use prior learning and create new learning and perform activities such as mind games and debates. One of the participant teachers stated, "I try to improve the meta-cognitive, cognitive, effort-regulation and time-regulation strategies with mind games (corridor, mangala, abalone, callisto) and chess games" $(T 18, M)$. Another teacher provided the following opinion: "I perform activities for goal-setting and -regulation, elaboration and organization strategies in the stages of communication, problem solving, group study and scientific research" $(T 13, M)$. It is observed that activities for improving meta-cognitive and motivational strategies are carried out following the cognitive strategies. The teachers reported that they carry out activities for meta-cognitive strategies such as goal setting and planning with student in small studies and also try to enhance students' motivation. One of the participant teachers stated, "I provide basic information to achieve the objective of the activity to be performed and try to maximize motivation by providing that basic information through rehearsal, elaboration and organization" (T16,M). Few participants reported that they carry our activities for effort-regulation, help-seeking, source-management strategies and strategies of regulating time and study environment in this program. One of the teachers reported, "Through group studies, performances of task sharing, responsibility taking and delivery are observed" $(T 15, M)$.

Table 5. Activities of Supportive Training Program and Self-Regulation Skills

\begin{tabular}{|c|c|c|c|}
\hline Theme & Subthemes & Codes & $\begin{array}{c}\text { Number of } \\
\text { Coding }\end{array}$ \\
\hline \multirow{7}{*}{$\begin{array}{c}\text { SUPPORTIVE TRAINING } \\
\text { PROGRAM }\end{array}$} & Meta-cognitive strategies & $\begin{array}{l}\text { Identifying the ways of learning (goal } \\
\text { setting) } \\
\text { Correction of incomplete or incorrect } \\
\text { knowledge (monitoring) } \\
\text { Goal setting } \\
\text { Improving the area of interest } \\
\text { Project planning (plan) }\end{array}$ & $\begin{array}{l}1 \\
2 \\
1 \\
1 \\
1\end{array}$ \\
\hline & Cognitive strategies & $\begin{array}{l}\text { Association with prior learning } \\
\text { (elaboration), organization } \\
\text { Keeping in mind, interpretation (elaboration } \\
\text { and meaning) } \\
\text { Mind games } \\
\text { Story completion (meaning making) } \\
\text { Debate, puzzles (rehearsal) } \\
\text { Rehearsal and organization }\end{array}$ & $\begin{array}{l}3 \\
1 \\
1 \\
1 \\
1 \\
1\end{array}$ \\
\hline & Motivation & $\begin{array}{l}\text { Verbal support, encouragement } \\
\text { Enhancing the confidence } \\
\text { Taking responsibility } \\
\text { Motivation }\end{array}$ & $\begin{array}{l}1 \\
1 \\
1 \\
2\end{array}$ \\
\hline & Effort regulation & & 1 \\
\hline & Help search & $\begin{array}{l}\text { Solidarity and cooperation } \\
\text { Group study }\end{array}$ & $\begin{array}{l}1 \\
2\end{array}$ \\
\hline & Source management & Problem solving, research & 3 \\
\hline & $\begin{array}{l}\text { Regulation of time and study } \\
\text { environ. }\end{array}$ & Time regulation & 1 \\
\hline
\end{tabular}


Table 6. Activities of Realizing Individual Abilities Program and Self-Regulation Skills

\begin{tabular}{|c|c|c|c|}
\hline Theme & Subthemes & Codes & Number of Coding \\
\hline \multirow{28}{*}{$\begin{array}{l}\text { REALIZING } \\
\text { INDIVIDUAL } \\
\text { ABILITIES } \\
\text { PROGRAM }\end{array}$} & \multirow{7}{*}{ Meta-cognitive strategies } & Planning & 1 \\
\hline & & Self-awareness & 2 \\
\hline & & Problem solving & 1 \\
\hline & & Planning, monitoring & 2 \\
\hline & & Creativity Improvement & 1 \\
\hline & & Setting the area of interest & 1 \\
\hline & & Goal setting & 1 \\
\hline & \multirow{8}{*}{ Cognitive strategies } & Use of prior knowledge & 1 \\
\hline & & Text interpretation & 2 \\
\hline & & Intelligence improvement/game & 1 \\
\hline & & Use of different ways & 1 \\
\hline & & Discussion & 1 \\
\hline & & Retentive information & 1 \\
\hline & & Rehearsal & 1 \\
\hline & & Organization & 2 \\
\hline & \multirow{8}{*}{ Motivation } & Curiosity, & 1 \\
\hline & & Motivation & 1 \\
\hline & & Positive feedback & 1 \\
\hline & & Encouragement for careful behavior & 1 \\
\hline & & Motivation & 2 \\
\hline & & Confidence improvement & 1 \\
\hline & & Impersonation/improvisation & 1 \\
\hline & & Adaptation & 1 \\
\hline & Effort regulation & & 1 \\
\hline & Help search & Project, Group work/job division & $\begin{array}{l}2 \\
1\end{array}$ \\
\hline & Source management & \multirow{2}{*}{ Source-seeking Project } & 2 \\
\hline & Regulation of time and study & & 2 \\
\hline & environment & & 1 \\
\hline
\end{tabular}

Table 6 indicates the teacher opinions on which self-regulation skills are improved by the activities performed during the Realizing Individual Abilities program. It is understood that the activities performed in this program are rather for cognitive, meta-cognitive and motivational strategies. The teachers reported that they carry out small projects with students who have specified their areas of interest perform activities for meta-cognitive strategies such as goal setting and planning and also conduct activities for cognitive strategies such as discussions, association between prior and recent learning. One of the participant teachers stated, "Once we asked students to write about something they are curious about in an activity. We wanted them to choose and prepare one of them. A student of mine wanted to raise chickens with incubator made by him/her. He/she first made a plan for that. Accordingly, he/she got information from diverse sources and people. He/she added that information to his/ her own knowledge and produced an incubator with simple materials he/she procured. We had chickens for four full term at BILSEM" (T1, F). Another teacher provided the following opinion for the history activities: "I rather carry out activities for cognitive strategies. While we try to find solution by holding a diwan meeting as in the Ottoman Empire, we do it for a current problem by organizing a cabinet meeting in the administration and administrators activity in the next week" (T12,F).

The teachers reported that absenteeism increases during this program; therefore they also perform activities to motivate students during small projects. The following is the opinion of a participant teacher on the matter: "I have students prepare small projects to motivate them in accordance with their interests and abilities. I make them feel each of their work is valuable through positive feedbacks $(T 14, F)$." Saying that they pay attention to exhibit students' activities, one of the participant teachers stated, "Exhibiting the products we produce in this program (National Anthems and our National Anthem, Mehmet Akif Ersoy Geography, Constructivist Grid, Passaparola) can encourage students to behave carefully about the activity" (T15, M). Another teacher stated, "Since the students in this group are intensively busy with the courses constantly and continuously, they are mostly in a bored and unwilling mood; so, I usually use the strategy of regulating the time and study environment and the organization strategy as well as the motivational strategy" $(T 23, F)$. One of the teachers who stated that he emphasizes project studies during this program reported that he uses self-regulation skills commonly in this process: "I am consulting for the projects in the contest "This is My Work" organized with the cooperation of MoNE and TUBITAK. I can list the most important self-regulation strategies which I aim to bring to my students as follows: Motivation, meta-cognitive, time and study environment, cognitive, effort regulation, help-seeking strategies, and source-management strategies" (T17,E).

Table 7 shows the teacher opinions on which self-regulation skills are improved by the activities performed during the Improving Special Skills program. The teachers stated that absenteeism increases because 
students attend courses for high school transition exams during this program, and the number of students in this program is low and students have difficulty in getting motivated (T1,F; T3,M). It is understood from the teacher opinions that the activities performed during this program are rather for improving the cognitive strategies. One of the teachers reported that he carries out activities for source management and cognitive strategies through research-find style projects $(\mathrm{T} 11, \mathrm{M})$. Another teacher reported that he performs activities for cognitive strategies during this program in the following statement: "What we do during this program are Line of Independence War, puzzle station, and the Archeological experience. If the activity can draw student's attention, the student can be more participative and productive" $(T 15, M)$. One of the teachers stated that she developed activities for producing products with students during this program: "Book writing (booklet, more like it.) Preparing 3-D materials, adapting a material used in the past to the present (for example, creating a calendar which recognizes the 12-animal Turkic calendar as 12 months)" (T12,F). Another teacher provided the following statement about producing a product based on the interdisciplinary principle:

"Activities using different skills together can be carried out. For instance, writing and acting in a play with friends can be effective during this program" $(T 20, F)$.

Table 8 shows the teacher opinions on which self-regulation skills are improved by the activities performed during the Project program. Since many of the Science and Art Centers have been opened recently, there are quite few students who have achieved this program. The teachers reported that the project subject is specified together with the student in accordance with the requests from students and the students use their self-regulation skills in this process. It is understood from the teacher opinions that the most used strategies are the meta-cognitive strategies during this program. One of the teachers stated, "After specifying the project subject, activities are performed to bring self-regulation skills in the stages of planning, goal setting, research, analysis, text creation, and reporting. Preparing a project already requires these skills. Many students acquire these skills during the process" (T12,F). Another teacher using the meta-cognitive strategies stated that he also uses strategies such as regulation of time and study environment: "I guide students toward the goal-setting strategy by writing the subject and goals on the whiteboard when deciding about the project subject through monitoring and questions about finding their own mistakes. I address the strategies of regulating time and study environment and planning by creating the project template plan" (T11,M).

Table 7. Activities of Improving Special Skills Program and Self-Regulation Skills

\begin{tabular}{|c|c|c|c|}
\hline Theme & Subthemes & Codes & Number of Coding \\
\hline \multirow{12}{*}{$\begin{array}{l}\text { IMPROVING } \\
\text { SPECIAL } \\
\text { SKILLS } \\
\text { PROGRAM }\end{array}$} & Meta-cognitive strategies & - & - \\
\hline & \multirow{6}{*}{ Cognitive strategies } & Interpretation activities & 1 \\
\hline & & Cognitive strategies & 3 \\
\hline & & Line of Independence War (meaning making) & 1 \\
\hline & & Puzzle station & 1 \\
\hline & & Creativity & 1 \\
\hline & & Playwriting & 1 \\
\hline & Motivation & - & - \\
\hline & Effort regulation & Preventing the behavior of demoralization & 1 \\
\hline & Help search & - & - \\
\hline & Source management & Project & 1 \\
\hline & $\begin{array}{c}\text { Regulation of time and study } \\
\text { environment }\end{array}$ & - & - \\
\hline
\end{tabular}

Table 8. Activities of Project Program and Self-Regulation Skills

\begin{tabular}{|c|c|c|c|}
\hline Theme & Subthemes & Codes & Number of Coding \\
\hline \multirow{11}{*}{$\begin{array}{l}\text { PROJECT } \\
\text { PROGRAM }\end{array}$} & \multirow{4}{*}{ Meta-cognitive strategies } & Selection of project subject (goal setting) & 3 \\
\hline & & Monitoring & 1 \\
\hline & & Planning & 2 \\
\hline & & Following history in an adventure & 1 \\
\hline & Cognitive strategies & Putting forth the ideal of Mehmet Akif & 1 \\
\hline & \multirow{2}{*}{ Motivation } & Motivation & 2 \\
\hline & & Confidence & 1 \\
\hline & Effort regulation & - & - \\
\hline & Help search & - & - \\
\hline & Source management & & 1 \\
\hline & $\begin{array}{c}\text { Regulation of time and study } \\
\text { environment }\end{array}$ & & 1 \\
\hline
\end{tabular}


Table 9. Need for In-Service Training (IST) on the improvement of self-regulation skills among the gifted

\begin{tabular}{cccc}
\hline & Theme & Codes & Number of Coding \\
\hline & & Learning different attributes & 1 \\
& & Being more useful/increasing competence & 11 \\
Self-regulation & Yes & Being in a different world & 1 \\
Need for IST & & Noticing different practices and examples & 1 \\
& & Professional education & 1 \\
& & I would like it & 4 \\
\cline { 2 - 4 } & No & I have enough knowledge. & 1 \\
\hline
\end{tabular}

Table 9 shows BILLEM teachers' opinion on the need for an in-service training on self-regulation strategies. Almost all teachers feel the need for an in-service training. Only one teacher reported that he/she does not need such an in-service training. Another teacher stated that she needs such trainings even more with the gifted education becoming important: "Education of gifted students have gained importance now. So, I think that teachers doing activities with such children must be equipped at the maximum level. I would certainly like to receive such a training. Students should be education the way it needs to be done" (T12,F). Similarly, another teacher stated, "I would like it. Doing such a training for increasing my competence on helping such children and reinforcing their formal education with more helpful methods would contribute to my profession" (T2,F). Another teacher who wants an in-service training provided the following opinion by stating that in-service training should be functional: " $I$ would like it. But first, it should make a contribution enough to provide material adaptation inasmuch as any it should involve techniques describing how any learning material (reading text, etc.) can be altered according to these strategies" $(T 11, M)$.

\section{Discussion and Conclusions}

The study indicates that it has some important results on self-regulation strategies used at Science and Art Centers (BILLSEM). BILLSEM teachers find themselves incompetent or partially competent for self-regulation skills. According to another result, the most important self-regulation deficiencies among BİLSEM students observed by the teachers are deficiencies of motivation and meta-cognitive strategies. As for the teacher opinions which stated that the students are deficient in meta-cognitive strategies, it was concluded that the students do not have goals and cannot make plans. When the literature is examined; many researchers emphasize that teachers should not see themselves adequately in self-regulation skills $[20,21,22,23,24,30,31]$. The lack of in-service training of teachers in this respect and the lack of self-regulation skills in undergraduate education can be attributed to the reasons for this deficiency.

Regarding the teacher opinions on bringing the self-regulation skills to students, most of the teachers think that BILLSEM curricula do not aim to provide students with the self-regulation skills. The fact that teachers have such an opinion can be due to lack of curriculum literacy. In some research on this issue, it is emphasized that teachers have in difficulty on understanding the curriculum and its objectives $[5,25,26]$. In addition, the teacher opinions on which self-regulation skills are developed by the activities done in the adaptation program at Science and Art Centers show that the teachers emphasize students' recognition and their adaptation to their peers, teachers and the Science and Art Center. It was concluded that the activities performed by the teachers are for improving the meta-cognitive strategies and motivational strategies during this program.

According to another result, the activities performed by the teachers who teach in the Support Training program are rather for improving the cognitive strategies. The teachers stated that they perform activities such as mind games and debates when developing the cognitive strategies. The teacher opinions on which self-regulation skills are developed by the activities performed in the Realizing Individual Skills program show that the activities are rather for cognitive, meta-cognitive and motivational strategies. As for which self-regulation skills are improved by the activities performed in the Improving Special Skills program, the teachers emphasize that absenteeism increases because students attend courses for high school transition exams, and therefore, the number of students is few in this program and students find it hard to be motivated. Finally, it is understood from the BILLEM teacher opinions on the need for an in-service training on self-regulation skills that almost all teachers need an in-service training. Much research is directly related to this finding $[27,3,26,28,29]$. The lack of in-service training of teachers in this respect and the lack of self-regulation skills in undergraduate education can be attributed to the reasons for this deficiency.

The following recommendations were made in accordance with the research results:

- It was concluded that BILSEM teachers who participated in the research do not have sufficient knowledge on self-regulation skills or strategies. It can be ensured that teachers teaching at these centers particularly receive in-service training on self-regulation skills and gifted education.

- This is a qualitative research. An interview form was used for receiving teacher opinions. An observation form can be prepared to make observations at BİLSEMs in a similar study in the future.

- The related literature indicates that there are few studies on gifted education and self-regulated 
learning skills. Similar research can be conducted to meet this gap in the literature at BILSEMs across different regions of Turkey.

\section{REFERENCES}

[1] Pintrich, P.R. (2000). The role of goal orientation in self-regulated learning. In M. Boekaerts, P. R. Bingölbali and M. Zeidner (Ed.), in Handbook of Self-Regulation: Theory, Research and Applications (p. 452-502)", San Diego, CA: Academic Pressfpintr.

[2] Risemberg, R., \& Zimmerman, B.J. (1992). Self-regulated learning in gifted students. Roeper Review, 15, 98-101.

[3] Zimmerman, B. J. (2000). Attaining Self-Regulation: A Social Cognitive Perspective. Boekaerts, M., Pintrich, P. R., Zeidner, M. (Ed.) Handbook of Self-Regulation (s. 13-39). Academic Press: California

[4] Cheng, E. C. K. (2011). The role of self-regulated learning in enhancing learning performance. The International Journal of Research and Review, 6(1), 1-16.

[5] Schunk, D. H. (2005).Self-regulation through goal setting, ERIC/CASS Digest 12-00, 1-6.

[6] Rajabi, S. (2012). Towards self-regulated learning in school curriculum. Procedia - Social and Behavioral Sciences 47, $344-350$

[7] Boekaerts, M. (1999). Self-regulated learning: Where we are today. International Journal of Educational Research, 31, $445-457$

[8] Winters F. I., Greene J. A. and Costich C. M. (2008). Self-regulation of learning within computer-based learning environments: A critical analysi., Educational Psychology Review, 20(4), 429-444.

[9] Pintrich, P. R. \& De Groot, E. V.(1990). Motivational and self-regulated learning components of classroom academic performance. Journal of Educational Pyschology, 82 (1), 33 40.

[10] Tannenbaum, J. A. (2003). Nature and Nurture of Giftedness, the Handbook of Gifted Education ( $3^{\text {rd }}$ ed.), N. Colangelo ve G. Davis (Eds.), Allyn ve Bacon, Boston. (45)

[11] Pintrich, P. R. (1998). The role of motivation in promoting and sustaining self-regulated learning. Journal of Educational Research, 31, 459-470.

[12] Zimmerman, B. J. (2002) Becoming a Self-Regulated Learner: An Overview, Theory Into Practice, 41(2), 64-70

[13] Renzulli, J. S. (1986). The Three Ring Conception of Giftedness: A Development Model or Creative Productivity. Cambridge. Cambridge Pres. (51-92).

[14] MoNE (MEB). (Milli Eğitim Bakanlığı). (2007). Bilim ve sanat merkezleri yönergesi, Ankara.

[15] Sezginsoy, B. (2007). Bilim ve sanat merkezi uygulamasının değerlendirilmesi. Yayımlanmamış Yüksek Lisans Tezi, Balıkesir Üniversitesi, Sosyal Bilimler Enstitüsü Eğitim Bilimleri Anabilim Dalı, Balıkesir.
[16] Kazu, İ.Y. and Senol, C., (2012).Views of teachers about gifted curriculum (Case of BİLSEM).International Journal of Educational Research. 3(2), 13-35

[17] Obergriesser, S., Steinbach, J., \& Stoeger, H. (2013). Emotional experience during participation in a program of self-regulated learning. International Conference on Talent Development \& Excellence Congress. September 25-28 2013, Antalya, Turkey

[18] Büyüköztürk, Ş. (2014).Sosyal Bilimler İçin Veri Analizi El Kitabı: İstatistik, Araştırma Deseni SPSS Uygulamaları ve Yorum

[19] Yildırım, A., and Simsek, H. (2005) Sosyal Bilimlerde Nitel Arastirma Yöntemleri (5th Ed.), Ankara: Seckin Publication.

[20] Zimmerman, B., Bonner, S., \& Kovach, D. (1996). Developing self-regulated learners: Beyond Achievement self-efficacy. Washington, DC: American Psychological Association.

[21] Kramarski, B. and Zeichner O. (2001). Using technology to enhance mathematical reasoning: Effects of feedback and self-regulation learning, Educational Media International, $38(2 / 3), 77-82$.

[22] Heo, H. (2000). Theoretical underpinnings for structuring the classroom as self-regulated learning environment. Educational Technology Intentional, 2(1), 31-51

[23] Housand, A., \& Reis, S. M. (2008). Self-regulated learning in reading: Gifted pedagogy and instructional settings. Journal of Advanced Academics, 20, 108-136.

[24] Treffinger, D.J. (1998) Teaching for self-directed learning: A priority for the gifted and talented. Gifted Child Quarterly, 19 (1), 46-59.

[25] Schunk, D.H., \& Zimmerman, B.J. (Eds.). (1994). Self-regulation of learning and performance: Issues and educational applications. Hillsdale, NJ: Erlbaum.

[26] Vandevelde, S., Van K. H. and Wever, D. B (2011).Exploring the impact of student tutoring on at-risk fifth and sixth graders' self-regulated learning. Learning and Individual Differences, 21, 419-425.

[27] Zimmerman, B. J., \& Martinez-Pons, M. (1990). Student differences in self-regulated learning: Relating grade, sex, and giftedness to self-efficacy and strategy use. Journal of Educational Psychology, 82, 51-59.

[28] Stoeger, H., \& Ziegler, A. (2005). Evaluation of elementary classroom self-regulatd learning program for gifted mathematics underachievers. International Education Journal, 6(2), 261-271.

[29] Bembenutty, H. (2011). Introduction: Self-Regulation of Learning in Postsecondary Education, New Directions for Teaching and Learning, n126 p3-8 Sum 2011. DOI: $10.1002 / \mathrm{tl} .439$

[30] Adigüzel, A., \& Orhan, A. (2017). The relation between English learning students' levels of self-regulation and metacognitive skills and their English academic achievements. Journal of Education and Practice, 8(9), 115-125.

[31] Yildırım, K. (2011). Felsefe (Kavramlar-Tarihçe-Alanlar-Problemler), Ankara: Yurtrenkleri Publication. 